\title{
Article
}

\section{Distancing from the Present: Nostalgia and Leisure in Lockdown}

Gammon, Sean James and Ramshaw, Gregory

Available at http://clok.uclan.ac.uk/33922/

Gammon, Sean James ORCID: 0000-0001-5053-8763 and Ramshaw, Gregory (2021) Distancing from the Present: Nostalgia and Leisure in Lockdown. Leisure Sciences, 43 (1-2). pp. 131-137. ISSN 0149-0400

It is advisable to refer to the publisher's version if you intend to cite from the work. http://dx.doi.org/10.1080/01490400.2020.1773993

For more information about UCLan's research in this area go to http://www.uclan.ac.uk/researchgroups/ and search for <name of research Group>.

For information about Research generally at UCLan please go to http://www.uclan.ac.uk/research/

All outputs in CLoK are protected by Intellectual Property Rights law, including Copyright law. Copyright, IPR and Moral Rights for the works on this site are retained by the individual authors and/or other copyright owners. Terms and conditions for use of this material are defined in the policies page.

\section{CLoK}

Central Lancashire online Knowledge www.clok.uclan.ac.uk

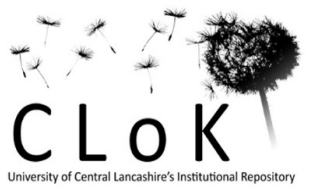




\title{
Distancing from the Present: Nostalgia and Leisure in Lockdown.
}

Sean Gammon: The University of Central Lancashire

\author{
Gregory Ramshaw: Clemson University
}

At this time, millions across the globe continue to endure the many restrictions of movement imposed by their governments, resulting in a renegotiation of how, where and when leisure takes place. Similarly, the freedom to look back and find comfort in pre-pandemic times has become a welcomed distraction across the generational spectrum. It may appear flippant in times of great crises to explore the behaviours and experiences of people at leisure. Yet, the leisure choices made in times of stress, anxiety and threat reveals much about the human condition, especially concerning life-affirmation and coping strategies. Whilst the therapeutic features of leisure are reasonably well documented (Kleiber et al 2011), discussions relating to the psycho-social benefits of leisure nostalgia has had little coverage. This commentary considers how nostalgia is affecting leisure choice(s), and how such choices are part of individuals' current coping strategies in lockdown. It will also examine how the leisure choices made during the crisis will inform the collective nostalgic reflections in the future.

There is little doubt that the global lockdown due to the spread of COVID-19 has profoundly affected our leisure choices and activities. It has also influenced with whom we are able to interact with during leisure and perhaps, more crucially, what is to be made with potentially more free time. Numerous commentators on leisure (Iso-Ahola, 1979; Neulinger, 1981; Kleiber et al, 2011) highlight that two critical components of leisure are freedom of choice and self-determination - each of which influences the quality of the experience. The lockdown coupled with social distancing has created a paradoxical situation that, on the one hand, dictates freedom constraint - whilst on the other seems to offer more time to engage in 
activities normally associated with individuals' leisure. Such enforced leisure (a term which may be considered oxymoronic) has led many to reflect on the value of leisure, especially in its ability to act as a buffer for stressful situations (Iso-Ahola \& Park 1996; Kleiber et al, 2011) and its propensity to add meaning and purpose in times of distress, loneliness and anxiety (Watkins 2000). Freedom of choice has not been extinguished - only the extent of its physical and spatial parameters. These restrictions (both real or imagined) have led to more creative uses of leisure, which unsurprisingly have taken place primarily in the home. As such, the third place is no longer reserved for those places that offer meaningful interaction '...outside the home and beyond the "work lots" of modern economic production' (Oldenburg and Brissett, 1982: p.269) but has become - through strict enforcement and social surveillance - the site of all forms of leisure and non-leisure activities. Unsurprisingly, technology has become the vehicle for many forms of leisure - including gaming, media streaming services (such as Netflix), social media, and virtual conferencing technology (such as Zoom). Perhaps more surprising is the role to which nostalgia has become one of the primary forms of this type of leisure consumption, including viewing old movies and shows, watching past sporting matches and competitions, and connecting with friends and family to share memories and reminisce. Similarly, other "at home" leisure activities such as cooking, baking, and exercise also have a nostalgic form to them, whether they reflect a nostalgic view of family bonding or, in the case of fitness, attempting to recapture our former, younger selves.

As the demographic of populations in most developed countries have notably got older in the last three decades, so has the interest in nostalgia (Gammon and Ramshaw, 2013; Youn \& Yin, 2017). In simple terms nostalgia refers to a sentimental longing for a past that has gone forever. It is often identified as an emotional response brought on by a dissatisfaction or detachment in the present, and an anxiety for the future (Batcho 1995; 
Davis, 1979). As a result, a seemingly superior, familiar and stable past is sought that is comprised of happier times which may generate mixed feelings of both joy and loss. Whilst nostalgia is mostly associated with those from older generations, younger people (those under 40 years) may also harken for simpler, less stressful times. Relentless advances in technology, economic recession, dramatic political change, and climate change (not to mention, of course, the "normalcy" of pre-pandemic society) can all be highlighted as triggers for this cross generational glance back towards calmer periods. Interpretations of nostalgia have changed over time - from a medical ailment in the seventeenth century to an overly romantic condition that was practiced by older generations - though, in general, it was viewed in pejorative terms; to be nostalgic was to be maudlin and unable to cope with the strange and unfamiliar present. Today, however, nostalgia is viewed in more affirmative terms, as generating numerous positive social and psychological functions for both young and old. For example, Sedikides et al (2008: 304) concluded that, 'nostalgia generates positive affect, increases self-esteem, fosters social connectedness, and alleviates existential threat', whilst Moore (2002) suggests that nostalgia can have a practical dimension in that positive reflections about past conditions can provide the framework for constructive future developments. Nostalgia has, in short, become an effective coping strategy to many of life's demands, by not only prompting us to recall more pleasant times - but also enabling individuals to remember how they felt during such times.

At time of writing, the lockdown has spawned a significant interest in the past; where young and old reflect on, and vicariously escape to, more predictable times; when friends could meet up, holidays taken, and events attended. Yet the pervasive manner in which nostalgia has been embraced by individuals, families, media, and politicians all point towards a collective anxiety that is bordering on the original pathological nature of nostalgia in the seventeenth century - in short, a "homesickness" which is less mawkish and more medical. 
Given that many positive experiences in the past are often leisure-related, it is unsurprising that nostalgia can be both a key trigger for leisure participation as well as an emotional reaction to it (Cho, 2020). In particular, forms of recent popular culture such as music (see: Barrett et al, 2010), film and television (see: Holdsworth, 2011), and sport (see: Gammon and Ramshaw, 2013) are frequently vehicles for popular nostalgia and, by extension, leisure consumption and participation. For example, studies focusing on the experiences of playing sport, watching sport and visiting sport attractions (Fairley, 2003; Ramshaw \& Gammon; 2010, Ramshaw, 2020) together with many forms of tourism illustrate the significance of past leisure events (Dann, 1998). This has led to a commodification of the past that involves either reintroducing previous brands to a market that remembers them the first-time around - or in the retrofication of bygone products aimed at more youthful markets who perceive them as ironic, authentic or edgy. As such, while nostalgia is a coping mechanism which helps to sooth in challenging times, it is also disseminated by various props and products which help us to long for indeterminate - but "better" - times. This is not to say that commerciallytinged nostalgia is necessarily harmful, but rather to note various routes to which individuals may come to - or be influenced by - nostalgia. To explore this further, the following section will discuss the numerous manifestations of nostalgia currently present in the COVID-19 crisis and reflect on it utility as a positive coping mechanism.

Family-based leisure is often considered in positive terms; as an incubator for future life satisfaction, well-being and socialisation. Yet the proliferation of technology in the home has in many cases helped nurture a more isolationist engagement with leisure, with individuals choosing to virtually socialise and interact with others outside the family than to spend time with them. At the same time E-leisure is viewed as an instigator of home leisure, offering more opportunities for shared experiences, socializing and intergenerational play. Of course, the extent that families engage in leisure is very much dependent on the age of the 
children, employment responsibilities of the parents or parent, and the nature of the housing and home environment. Nevertheless, there remains a societal pressure to provide meaningful family leisure experiences which in many circumstances are unrealistic and unachievable (Shaw and Dawson, 2010). Evidence suggests that the lockdown has in some way assuaged the guilt of parents for not providing meaningful family leisure by introducing off-line games from yesteryear to their children. Messages and images in a variety of social media platforms show families engaging in variety of traditional board and card games in an attempt to reconnect to the way families used to play - or were thought to. A recent article in the Telegraph underlines the perceived benefits of spending quality time with the family, citing: In the era of self-isolation, many of us are remembering that the chance to spend time with other people, to sit around the kitchen table with our households, is a treat (Rear, 2020). Clearly the mixture of leisure and nostalgia during difficult times offers a palliative respite through social interaction, distraction and escape. At present, individuals in the UK for example have government permission to, once a day, literally break free from the confines of the home. In many cases families have decided to do this together which has helped reduce tension and promote conversation - an event considered less exceptional forty years ago.

The media in all its guises has both fuelled and reacted to the current surge in nostalgia by offering reminders of the way things were before the virus spread. Some TV and radio channels regularly offer repeats of long since forgotten drama series', musical artists provide "couch tours" where they rebroadcast past concerts (or perform live, in quarantine, from their homes via social media channels), whilst other broadcasters replay sports matches from both the recent and distant past. The BBC recently aired the radio commentary for the final day of the cricket Ashes series (England v Australia) in 2019. Many thousands tuned in to not only relive an extraordinary sporting moment, but also to switch off from the grim realities of the present and to be immersed in a perfect, unchanging past. Such collective 
nostalgia (see Gammon, 2002) has proved extremely popular with other recordings of previous games such as famous matches in soccer, rugby, tennis and snooker. Social media platforms have also latched onto the nostalgic zeitgeist by offering users to discuss and vote for their favourite sporting moments, team jersey or greatest athlete. Similarly, in the US, sports broadcasters have filled much of their now-empty schedules with rebroadcasts of past matches - some famous (such as championship games or record-breaking performances) as well as the more mundane (e.g.: pre-pandemic competitions from January and February 2020), interspersed with the occasional current sports story (such as NFL free agency and the NFL draft) and the near-daily speculation about when professional and collegiate sport will return. Whilst the use and projection of nostalgic imagery in the media is not a new phenomenon (Niemeyer, 2014), the current celebration of the past is indicative of a media keen in promoting and benefitting from current anxieties. Airtime and column inches that would usually be devoted to sport have been replaced with reflective narratives and images that fills not only what would otherwise be a commercial certainty - but also partly satisfies a public of their beloved sport.

Alongside the nostalgically positioned articles in the press, politicians across Europe and North America have been dredging the past in order to rally their nations' resolve in these times of crisis. "Looking out for each other" and the reification of local and national community appear to be the most common messages; reinforced with explicit reminders that we have endured far worse. Such nostalgic rhetoric sits well with the many current political ideologies around the globe that aim to re-establish glories and achievements of the past (Kenny, 2017). A recent national broadcast by Queen Elizabeth also highlighted the importance of support and resolve whilst adding that future generations will look back at how the current generation coped during the current economic and social restrictions. This observation relates to an often-neglected facet of nostalgia, coined as nowstalgia that 
involves the planning, production and distribution of visual documents in the present for the purpose of nostalgic refection in the future (Korin, 2016). The ubiquitous cell phone is increasingly used to capture much of our lives as they happen - but at the expense of experiencing them at the time. Focus on involvement and immersion during leisure episodes is being replaced by considerations of how best to capture and share them on social media. This may act as an additional coping mechanism that helps dilute the seriousness of the present situation whilst optimistically planning for the future - in essence, creating a "do you remember when?" moment for our future selves to nostalgise and consume.

Clearly, for many, nostalgia-inspired leisure has been a "cocktail for coping" and has had a palliative affect during the initial stages of the pandemic. Reflecting on the knowable and comforting past is far more enjoyable - and far less anxiety-inducing - than contemplating a traumatic present and a potentially bleak future. The lockdown may also become a source of nostalgia once the pandemic is over, as we may end up having sentimental attachments to the times we watched old movies together, went for walks, baked bread - and, collectively, defeated the coronavirus. Of course, having both leisure - and the space (and, perhaps, boredom) to experience nostalgia - is also a privilege that many essential workers have not experienced during the lockout, while for others "sheltering at home" has created or exacerbated feelings of anxiety, helplessness, depression and, in some cases, risk from domestic violence. Furthermore, many will have lost a loved one during the pandemic often, without being able to give their final goodbyes in person - and, as such, this time will hardly be viewed through rose-coloured glasses. Our immediate social and economic future also appears bleak, perhaps causing some to permanently retreat into the nostalgic past rather than facing an immensely unknowable future. Moreover, to employ an old axiom, nostalgia isn't what it used to be, particularly in terms of future commercial consumption and products. For example, mere weeks after the lockdowns in Western Europe and North America, sports 
leagues turned to broadcasting e-sports competitions with many (such as NASCAR iRacing competitions in the US) attracting significant viewership (Gastelu, 2020). Other forms of cultural consumption, such as going to museums and galleries, and attending live performances, may only be able to survive on rebroadcasting and repackaging for so long. As such, while nostalgia may have soothed our jangled nerves initially, it may also have a limited shelf-life particularly if the lockdown lingers on.

\section{References}

Barrett, F. S., Grimm, K. J., Robins, R. W., Wildschut, T., Sedikides, C., \& Janata, P. (2010). Music-evoked nostalgia: Affect, memory, and personality. Emotion, 10(3), 390.

Batcho, K. (1995) Nostalgia: a psychological perspective. Perceptual and Motor Skill 80(1), 131-143

Cho, H. (2020) Importance of leisure nostalgia on life satisfaction and leisure participation. The Service Industries Journal, 40(1-2), 90-109

Dann, GMS, (1998) 'There's no business like old business': tourism, the nostalgia industry of the future. In Theobald, W. (ed.) Global Tourism, London: Routledge, pp. 29-43

Davis, F. (1979) Yearning for Yesterday: A Sociology of Nostalgia. New York: Free Press Iso-Ahola, S. (1979) Basic dimensions of definitions of leisure. Journal of Leisure Research, 11(1), 28-39.

Iso Ahola, S. and Park, C. J. (1996) Leisure-related social support and self-determination as buffers of stress-illness relationship. Journal of Leisure Research. Journal of Leisure Research, 28(3), 169-187.

Fairley, S. (2003) In search of relived social experience: group-based nostalgia. Journal of Sport Management, 17(3), 284-304

Gammon, S. (2002) Fantasy, nostalgia and the pursuit of what never was. In Gammon, S. and Kurtzman, J. (eds) Sport Tourism: Principles and Practice. Eastbourne: LSA Publications, pp. 61-70.

Gammon, S. and Ramshaw, G. (2013) Nostalgia and Sport. In Fyall, A. and Garrod, B. (eds) Contemporary Cases in Sport. London: Goodfellow Publishers, pp.201-219.

Gastelu, G. (2020). Fox's virtual NASCAR race sets esports record with 1.3 million viewers. Available online at https://www.foxnews.com/auto/foxs-virtual-texas-nascar-esports-record

Kalinina, E. (2016) What do we talk about when we talk about media and nostalgia? Medien and Zeit, 4, 6-15. 
Kenny, M. (2017) Back to the populist future?: understanding nostalgia in contemporary ideological discourse. Journal of Political Ideologies, 22(3) 256-273.

Kleiber, D.A., Walker, G.J. and Mannell, R. C. (2011) A Social Psychology of Leisure (2 $2^{\text {nd }}$ ed.). Venture Publishing: IllinoisKorin, E. (2016) Nowstagia. Articulating future pasts through selfies and gopro-ing. Medien and Zeit, 4, 50-60.

Moore, P. (2002). Practical nostalgia and the critique of commodification: On the 'Death of Hockey'and the National Hockey League. The Australian journal of anthropology, 13(3), 309-322.

Niemeyer, K. (2014). Media and nostalgia. Yearning for the past, present and future. Basingstoke, Hampshire.

Neulinger, J. (1981) The Psychology of Leisure. Charles C Thomas: Springfield Illinois.

Oldenburg, R. and Brissett, D. (1982) The third place. Qualitative Sociology, 5(4), 265-284

Ramshaw, G. (2020). Heritage and Sport: An Introduction. Bristol: Channel View.

Ramshaw, G. and Gammon, S. (2010) On Home Ground? Twickenham Stadium Tours and the Construction of Sport Heritage. Journal of Heritage Tourism 5(2), 87-102

Rear, J. (2020) The best board game to alleviate boredom during lockdown. Telegraph online: www.telegraph.co.uk/family/life/best-board-games-alleviate-boredom-lockdown/ (accessed 20/04.2020)

Shaw, S.M and Dawson, D. (2010) Contradicting aspects of family leisure: indealization versus experience. Leisure/Loisir. 28(3-4), 179-209.

Sidikides, C., Wildschut, T., Arndt, J. and Routledge, C. (2008) Nostalgia: past, present, and future. Current Directions in Psychological Science, 17(5), 304-307.

Watkins, M. (2000) Ways of learning about leisure meanings. Leisure Sciences, 22(2), .93101.

Youn, S. and Jin, S. V. (2017) Reconnecting with the past in social media: the moderating role of social influence in nostalgia marketing on Pinterest. Journal of Consumer Behaviour, $16(6), 565-576$. 